\title{
Young maiden mares can also be susceptible to a persistent mating-induced endometritis
}

\author{
Eduardo Malschitzky 1,2, Cristina Rodrigues Trein ${ }^{1}$, Ivan Cunha Bustamante Filho', Petra Garbade?, Ricardo Macedo Gregory ${ }^{l}$ and \\ Rodrigo Costa Mattos ${ }^{1 *}$
}

Reprolab, Departamento de Medicina Animal, Faculdade de Veterinária, Universidade Federal do Rio Grande do Sul' and Curso de Medicina Veterinária, Universidade Luterana do Brasil².

\begin{abstract}
Summary
The aim of this study was to investigate the presence of persisting mating-induced endometritis in maiden mares compared with the incidence in barren mares and to test the efficiency of a certain intra-uterine treatment. Seventy maiden Thoroughbred mares aged between 3 and 8 years and 69 barren mares were studied. Mares were examined daily by means of palpation and ultrasound per rectum in order to evaluate follicular growth, grade of uterine edema and presence of intrauterine fluid accumulation (IUF). Mares were allowed to breed when the follicle reaches $>40 \mathrm{~mm}$, associated with a reduction of the uterine edema. Twelve stallions with known fertility were used. A second examination was performed per rectum 36-48 h after breeding in order to confirm ovulation, to evaluate the uterine state and to verify the closure of the cervix. All mares showing any amount of IUF 36-48 h after breeding were submitted to uterine flushing followed by an infusion of antibiotics. We conclude that (1) the incidence of persistent mating-induced endometritis in maiden mares is comparable to the findings in barren mares; (2) the early closing of the cervix is an important mechanism in endometritis pathogenesis of maiden mares, independent of the individual age; (3) the presence of IUF during estrus in maiden mares is not a good marker for the uterine clearance as it is for other groups; (4) Maiden mares with post breeding endometritis and treated with an association of uterine flushing and an infusion of antibiotics revealed pregnancy rates similar to reproductive healthy mares, even when the treatment is done 36-48 hours after mating.
\end{abstract}

Keywords: Maiden mares, endometritis, intrauterine fluid, therapy

\section{Junge Maidenstuten können auch empfänglich für eine persistierende Post-Breeding-Endometritis sein}

In dieser Untersuchung wird das Auftreten einer persistierenden „Post-Breeding Endometritis" (PBE) bei Maidenstuten und güsten Stuten sowie die Effizienz verschiedener Behandlungen verglichen. 70 Vollblutmaidenstuten (3-8 Jahre) und 69 güste Stuten wurden in die Studie einbezogen. Die klinischen Untersuchungen umfassten eine tägliche rektale Palpation sowie eine transrektale Ultrasonographie zur Follikelkontrolle, zum Nachweis eines Uterusödems sowie einer intrauterinen Flüssigkeitsansammlung (IUF). Die Belegung erfolgte durch 12 verschiedene Hengste mit bekannter Fertilität bei Erreichen eines Follikeldurchmessers $>40 \mathrm{~mm}$ und Reduktion des uterinen Rosseödems. Eine Kontrolluntersuchung zur Dokumentation der Ovulation, des Zervixschlusses sowie zur Erhebung des Uterusstatus wurde 36-48h später vorgenommen. Alle Stuten mit jeglicher IUF nach der Belegung wurden einer Uterusspülung mit anschließender Infusion einer Antibiotikalösung unterzogen. Resultate: 1. Die Inzidenz einer persitierenden PBE bei Maidenstuten ist derjenigen bei güsten Stuten vergleichbar. 2. Ein schneller Schluss der Zervix ist ein wesentlicher pathogenetischer Faktor bei der klinischen Manifestation einer persitierenden PBE. 3. Die IUF als Marker für die uterine Clearance im Östrus erweist sich bei Maidenstuten, verglichen mit anderen Stuten, als wenig aussagekräftig. 4. Maidenstuten mit einer PBE, die mittels Spülung und einer uterinen Antiobiotikainfusion behandelt werden, weisen eine gesunden Patienten vergleichbare Trächtigkeitsrate auf, auch wenn die Behandlung 36-48h nach der Belegung stattgefunden hat.

Schlüsselwörter: Reproduktion, Maidenstuten, Endometritis, intrauterine Flüssigkeit, Therapie

\section{Introduction}

It is known for years that breeding of a mare is followed by inflammatory endometrial reactions (Katila 1997). Spermatozoa provoke an inflammatory response in the mare's uterus after breeding or insemination (Kotilainen et al. 1994). The uterus must be able to clear the uterine contamination (microorganisms and inflammatory byproducts) spontaneously within the first five days after conception. The uterine clearance is easily accomplished by resistant mares, while susceptible mares often fail to clear the uterus within this time. It is documented in the literature that an impaired physical clearance is the main factor involved in the susceptibility to a persistent endometritis (Troedsson 1997a). Myometrial contractions are more effective in the estrogen domina- ted estrus, stimulating the uterus to eliminate its contents through the open cervix. (Evans et al. 1986). In general, a loss of resistance to infections is associated with advancing age and parity (Asbury and Lyle 1993). The incidence of intrauterine fluid until two days after natural breeding in Thoroughbred mares is 15\% in 746 cycles investigated (Zent et al. 1988) and $43 \%$ in 552 cycles investigated in a mixed population of mares (Newcombe, 1977). Pregnancy rates in the latter study were $49 \%$ in mares with intrauterine fluid within $48 \mathrm{~h}$ after mating compared with $62 \%$ in mares without fluid. In a retrospective study dealing with 1393 mares, Morris and Allen (2001) observed that only 3,9\% of the maiden mares accumulated uterine fluid, followed by uterine treatments after breeding compared to barren (14.9\%) and foaling (13.8\%) mares. 
Persistent mating induced endometritis commonly causes infertility in multiparous mares older than 14 years (LeBlanc 1997). Although pregnancy rates were reduced by intrauterine fluid during estrus in a further report (Pycock and Newcombe 1996), fluid, collected from most of the mares had negative bacteriology and cytology results and therefore was not of inflammatory origin (Pycock and Newcombe 1996; Reilas et al. 1997). Estrogen influences the uterus during estrus, increasing endometrial secretion and uterine edema. It is discussed that in mares with uterine fluid accumulations during estrus more glands show larger diameter and wider lumina compared with mares without intrauterine fluid (Rasch et al. 1996). This might suggest that hypersecretion of mucus contributes to intrauterine fluid accumulation (Watson 2000). However, fluid drainage via cervix and lymphatics is also important and mares which intrauterine fluid accumulations are suspected to have cervical fibroses or anatomical changes, often age associated, resulting in a pendulous or ventrally tilting uterus (LeBlanc et al. 1998). In other cases lymphatic drainage may be impaired as well (LeBlanc et al. 1995).

Maiden mares, regardless of their age, may also develop persisting mating-induced endometritis, because the cervix does not relax sufficiently during estrus to allow drainage of uterine fluids. This condition occurs most commonly in aged performance maiden mares being firstly bred when they are in their teens (LeBlanc 2003a). Often an older maiden mare has an abnormally tight cervix which fails to relax properly during estrus so that fluid is unable to drain and accumulates in the uterine lumen (Pycock 1993). This condition occurs in young nervous mares as well. The cause of the malfunction is not known. The problem appears to be resolved when the mares have delivered their first foal (LeBlanc 2003a).

This study was carried out to verify the presence of persisting mating-induced endometritis in maiden mares and to compare the incidence with the findings in barren mares and to investigate the efficiency of an intra-uterine treatment.

\section{Material and Methods}

Seventy maiden Thoroughbred mares aged between 3 and 8 years old were studied. The mares were retired from training and sent to a breeding center in south Brazil. Barren mares $(n=69)$ were used as control animals. Maiden and barren mares were pastured and supplemented with oats and hay in individual boxes. All mares were submitted to an artificial photoperiod $\left(10 \mathrm{w} / \mathrm{m}^{2}\right)$ with $15 \mathrm{~h}$ light and $9 \mathrm{~h}$ darkness since the 15th May. Mares were examined by means of palpation and ultrasound per rectum daily in order to evaluate follicular growth, grade of uterine edema and presence of intrauterine fluid accumulation (IUF). Uterine edema was classified in a scale from 1 (no edema) to 3 (strong edema). Mares were allowed to breed when a follicle $>40 \mathrm{~mm}$ and a reduced of uterine edema was detected. Twelve stallions with known fertility were used. A second examination was performed per rectum 36-48 h after breeding in order to confirm ovulation, to evaluate the uterine state and to verify the closure of the cervix $(0=$ open; $3=$ closed). All mares showing any amount of IUF 36-48 h after breeding were considered to have an persistent mating-induced endometritis and were submitted to uterine flushing (at least three flushes with $2 \mathrm{~L}$ rin- ger-lactate each), followed by an infusion of $5 \times 10^{6} \mathrm{IU}$ of penicillin $\mathrm{K}$ or $1.6 \mathrm{~g}$ of gentamicin. Mares with IUF for more than 3 consecutive days, in spite of treatment, were excluded from this study.

Pregnancy diagnosis was performed 12 days after ovulation. Mares presenting an embryonic vesicle were examined once a week until the 42 nd day of gestation. Twins were manually reduced until the 16th day after ovulation. Pregnancy losses occurring between the first diagnosis and the 42nd day of pregnancy were recorded as embryonic death (ED). Pregnan$c y, E D$ rates and IUF incidence were analyzed using Chisquare test. Differences were considered significant at $\mathrm{P}<0.05$.

\section{Results}

No significant differences $(P=0.06)$ were observed between the percentage of persistent mating-induced endometritis in maiden and barren mares (Tab. 1). While in $75 \%$ of the maiden mares with a persistent mating-induced endometritis a

Tab 1 Occurrence of persistent mating-induced endometritis (IUF 36-48 h after breeding) in maiden and in barren mares. Häufigkeit einer persistierenden PBE (IUF 36-48h nach der Belegung) bei Maidenstuten und güsten Stuten.

\begin{tabular}{|c|c|c|c|}
\hline Mares & $\mathrm{n}$ & \multicolumn{2}{|c|}{ Persistent mating-induced endometritis } \\
\cline { 3 - 4 } & & $\mathrm{n}$ & $\%$ \\
\hline Maiden & 70 & $16^{\circ}$ & 22.8 \\
\hline Barren & 69 & $26^{\circ}$ & 37.7 \\
\hline
\end{tabular}

Same superscripts (a) within each column indicate no significant difference $\left(1^{2}=3.621 ; P=0.06\right)$

Tab 2 Occurrence of persistent mating-induced endometritis (IUF 36-48 h after breeding) in maiden mares with a closed cervix.

Auftreten einer persistierenden PBE (IUF 36-48h nach der Belegung ) bei Maidenstuten mit geschlossener Zervix.

\begin{tabular}{c|c|c|c|}
\hline $\begin{array}{c}\text { Persistent mating- } \\
\text { induced endometritis }\end{array}$ & \multirow{n}{*}{$\mathrm{n}$} & \multicolumn{2}{|c|}{ Mares with closed cervix } \\
\cline { 3 - 4 } & & $\mathrm{n}$ & $\%$ \\
\hline Presence & 16 & $12^{\mathrm{a}}$ & 75 \\
\hline Absence & 54 & $0^{\mathrm{b}}$ & 0 \\
\hline
\end{tabular}
$\begin{aligned} & \text { Different superscripts }(\mathrm{a}, \mathrm{b}) \text { in the same column indicate significant difference between values } \\
& \left(\mathrm{c}^{2}=48.94 ; \mathrm{P}<0.01\right)\end{aligned}$

closed cervix in the post-breeding examination was obvious, none of the mares without IUF (Tab. 2) showed such findings $(P<0.01)$. No differences were observed in the pregnancy rates 12 and 42 days after ovulation and the embryonic death rate $(P=0.80)$ between maiden mares without IUF after breeding and maiden mares with persistent mating-induced endometritis treated with intrauterine flushing and antibiotic infusions (Tab. 3). There were no statistical significant differences between the degree of the uterine edema and the closure of the cervix in the maiden mares investigated after breeding (Tab. 4). The presence of IUF during estrus did not correlate with the incidence of persistent mating-induced endometritis (Tab. 5).

\section{Discussion}

The presence of IUF and its deleterious effects on fertility are widely known in barren mares (Newcombe 1997) and in mares bred in the foal heat (Malschitzky et al. 2002). 
Tab 3 Pregnancy rates at 12 and 42 days after ovulation and embryonic death (ED) in maiden mares without presence of IUF 36-48 $\mathrm{h}$ after breeding and maiden mares with persistent mating-induced endometritis treated with intrauterine lavage and infusion of antibiotics.

Trächtigkeitsrate 12 und 42 Tage nach der Ovulation und embryonale Verluste (ED) bei Maidenstuten ohne IUF 36-48h nach der Belegung und solchen Maidenstuten, die wegen einer persistierenden PBE mittels einer intrauterinen Lavage und Antibiotikainfusionen behandelt wurden.

\begin{tabular}{|c|c|c|c|c|c|c|}
\hline $\begin{array}{c}\text { Persistent mating } \\
\text { endometritis }\end{array}$ & $\mathrm{n}$ & \multicolumn{2}{|c|}{ Pregnant at Day 12 } & \multicolumn{2}{c|}{ Preganant at Day 42 } & $\mathrm{ED}$ \\
\cline { 3 - 7 } & & $\mathrm{n}$ & $\%$ & $\mathrm{n}$ & $\%$ & $(\%)$ \\
\hline Presence & 16 & $11^{\circ}$ & 68.7 & $10^{\circ}$ & 62.5 & 9.1 \\
\hline Absence & 54 & $35^{\circ}$ & 64.8 & $34^{\circ}$ & 62.9 & 2.8 \\
\hline
\end{tabular}

Tab 4 Occurrence of a closed cervix 36-48 h after breeding in maiden mares versus uterine estrus edema.

Auftreten einer geschlossenen Zervix 36-48h nach der Belegung bei Maidenstuten in Relation zum uterinen Östrusödem.

\begin{tabular}{|c|c|c|}
\hline Edema & \multicolumn{2}{|c|}{ Mares with closed cervix } \\
\hline (grade) & $\mathrm{N}$ & $\%$ \\
\hline $1,5-2,0$ & $8^{a}$ & 66.6 \\
\hline $2,5-3,0$ & $4^{a}$ & 33.3 \\
\hline
\end{tabular}

Tab 5 Occurrence of intrauterine fluid accumulation (IUF) during estrus in maiden mares with and without persistent mating-induced endometritis (IUF 36-48 after breeding).

Auftreten einer intrauterinen Flüssigkeitsakkumulation (IUF) im Östrus bei Maidenstuten mit und ohne eine persistierende PBE (IUF 36-48h) nach der Belegung.

\begin{tabular}{|c|c|c|c|}
\hline $\begin{array}{c}\text { persistent mating } \\
\text { endometritis }\end{array}$ & $\mathrm{N}$ & \multicolumn{2}{|c|}{ IUF during estrus } \\
\cline { 2 - 4 } & & $\mathrm{N}$ & $\%$ \\
\hline Presence & 16 & $4^{\mathrm{a}}$ & 25.0 \\
\hline Absence & 54 & $4^{\mathrm{a}}$ & 7.4 \\
\hline
\end{tabular}
Same superscripts (a) within each column indicate
no significant difference $\left(c^{2}=3.766 ; P>0.05\right)$.

Alterations of the endometrial glands and vessels, as well as abnormalities of uterine positioning within the abdominal cavity are related to age and parity (Ricketts and Alonso 1991, Schoon et al. 1997) and mainly irreversible. However, according to Vieira et al. (2002) there is no relation between uterine fluid accumulation and the classification of biospies when using IUF after Al as a criteria for declaring mares as "resistant" (no IUF until 48 hours post Al) and "susceptible" (persistent IUF after 48 hours post Al). Following this criteria, we did not find significant differences concerning the occurrence of persistent mating-induced endometritis between maiden and barren mares. Maiden and young mares ( $<5$ years) are mostly considered as "endometritis-resistant", based on their responses to experimental infections (Hughes and Loy 1975; Evans et al. 1986). Our results disagree with this statement. In this study we could show that persistent mating-induced endometritis in maiden mares is a potential cause of reproductive failure as well, suggesting that this group should be treated as barren mares, a population which is believed to have most "susceptible" individuals.

A malfunction of the cervix with an early closing was observed in $75 \%$ of mares with IUF $36-48$ hours post mating, possibly related with endometritis pathogenesis. These results agree with LeBlanc (2003b), who considers that a cervix malfunction is the major cause of uterine physical clearance failure in maiden mares. Pycock (2000) described this cervix problems as a syndrome in older ( $>10$ years) maiden mares. In our study we used younger individuals (mean age $=4.6$ years), the results demonstrate the importance of a complete clinical evaluation of the uterus, focussing on the presence of IUF and persisting post breeding endometritis (PBE), cervix aperture after mating (mares of all ages) and the reproductive status. This will help to identify risk patients and to choose the best treatment, if necessary.

In this study, treatment was based on uterine lavages followed by infusion of antibiotics. Pregnancy rates of treated and healthy mares did not show significant differences. We choosed this treatment regime because there was a large interval between mating and uterus evaluation. Pycock (1993) describes good results obtained by a treatment with oxytocin, associated with a manual opening of the cervix. He suggests an clinical investigation until the first 12 hours after mating. Positive treatment results were achieved as well by a physical stimulation of the uterine clearance (uterine flushing and administration of ecbolic drugs) in mares classified as highly susceptible to endometritis and mares mated at foal heat (Troedsson 1997b, Knutti et al. 2000, Malschitzky et al. 2002). Nevertheless the success of this treatment depends on an early examination of the mares until 12 hours after mating. Often this will not be possible, the only alternative is a previous determination of risk mares, which might have to be treated.

Twenty five percent of mares with IUF during estrus had persistent mating-induced endometritis, similar when compared with mares without IUF. These results contrast with those of Leendertse (1997) and Schilela et al. (2001), obtained in barren and foaling mares. In these two groups, the presence of IUF during estrus may be considered as an indicator for uterine physical clearance failure.

It was not possible to identify any relation between early cervix closing and the maximum degree of the uterine edema during estrus in the present study. However, due to the small number of animals, it's not possible to exclude effects of a lower plasmatic estrogen concentration in these mares, or a lack of synchrony between the steroid hormone levels and the expression of its receptors at the cervix, as seen in the endometrium (Schoon et al. 2000). A high concentration of oxytocin receptors was found in the cervical mucosa of cows during estrus, suggesting a role of this hormone on cervix opening, induced by prostaglandin E2 (Fuchs et al. 1996). Prostaglandin E2 is also responsible for the opening of the cervix at the time of parturition in the mare (Ginther 1992).

We conclude that (1) the incidence of persistent mating-induced endometritis in maiden mares is comparable with the incidence of PBE in barren mares; (2) the early closing of the cervix is an important mechanism in the pathogenesis of endometritis in maiden mares independent of the age; (3) the presence of IUF in maiden mares during estrus is not a good marker for the uterine clearance as it is for other groups of mares; (4) maiden mares with post breeding endometritis treated with an association of uterine flushing and infusion of antibiotics revealed pregnancy rates similar to reproductive healthy mares, even when the treatment was done 36-48 hours after mating. 


\section{Literature}

Asbury A. C. and S. K. Lyle (1993): Infectious causes of infertility. in: McKinnon A.O. and J.L. Voss, Equine Reproduction. Philadelphia, Lea\&Febiger, 392-396

Evans M. J.; J. M Hamer; L. M Gason; C. S. Graham Asbury and C. H. G. Irvine (1986): Clearance of bacteria and non-antigenic markers following intra-uterine inoculation into maiden mares: effect of steroid hormone environment. Theriogenology 26, 37-50

Fuchs A. R.; R. Ivell, P. A. Fields, S. M. Chang and M. J. Fields (1996): Oxyłocins receptors in bovine cervix: distribution and gene expression during the estrous cycle. Biol. Reprod. 54, 700-708

Ginther O. J. (1992): Reproductive Biology of the Mare. Cross Plains: Equiservices, 470

Hughes J. P. and R. G. Loy (1975): The relation of infection and infertility in the mare and stallion. Equine Vet. J. 7,155-159

Katila T. (1997): Interactions of the uterus and semen. Pferdeheilkunde 13, 508-511

Knutti B., J. F. Pycock, G. C. Van Der Wijden and U. Küpfer (2000): The influence of early postbreeding uterine lavage on pregnancy rate in mares with intrauterine fluid accumulations after breeding. Equine Vet. Edu. 12, 276-270

Kotilainen T., M. Huhtinen and T. Katila (1994): Sperm-induced leucocytosis in the equine uterus. Theriogenology 41,629-636

LeBlanc M. M. (1997): Effects of oxitocin, prostaglandin and phenylbotazone on uterine clearance of radiocolloid. Pferdeheilkunde, $13,483-485$

LeBlanc M. M. (2003a): Persistent Mating induced Endometritis in the Mare In: Robinson, N.E. Current Therapy on Equine Medicine 5. Philadelphia, W.B.: Saunders, 234-237

LeBlanc M. M. (2003b): Persistent Mating induced Endometritis in the Mare. In: Ball, B.A. Recent Advances in Equine Reproduction, New York, IVIS (www.ivis.org)

LeBlanc M. M., R. D. Johnson, M. B. Calderwood Mays and C. Valderrama (1995): Lymphatic clearance of india ink in reproductively normal mares and mares susceptible to endometritis. Biol. Reprod., Mono. 1, 501-506

LeBlanc M. M., L. Neuwirth, L. Jones, C. Cage and D. Mauragis (1998): Differences in uterine position of reproductively normal mares and those with delayed uterine clearance detected by scintigraphy. Theriogenology 50, 49-54

Leendertse I. P. (1997): The Ultrasonographic Detection of Uterine Fluid During the Oestrus Cycle: Assessment and Management on a Thoroughbred Breeding Farm (Abstract). Pferdeheilkunde 13, 544

Malschitzky E., A. Schilela, A. L. G. Mattos, P. Garbade, R. M. Gregory and R. C. Mattos (2002): Effect of Intra-uterine fluid accumulation during and after foal-heat and of different management techniques on the postpartum fertility of thoroughbred mares. Theriogenology 58, 495-498

Morris L. H. A. and W. R. Allen (2001): Reproductive efficiency of intensively managed Thoroughbred mares in Newmarket. Pferdheilkunde 17, 548-556

Newcombe J. R. (1997): The effect of the incidence and depth of intra-uterine fluid in early dioestrus on pregnancy rate in mares (Abstract). Pferdeheilkunde 13, 545
Pycock J. F. (1993): Cervical function and uterine fluid accumulation in mares. Equine Vet. J. 25, 191

Pycock J. F. (2000): The old maiden mare syndrome. In: Samper, J.C. Equine Breeding Management and Artificial Insemination. Philadelphia, W.B. Saunders, 306

Pycock J. F. and J. R. Newcombe (1996): The relationship between intraluminal uterine fluid, endometritis, and pregnancy rate in the mare. Equine Pract. 18, 19-22.

Rasch K., H-A. Schoon, H. Sieme and E. Klug (1996): Histomorphological endometrial status and influence of oxytocin on the uterine drainage and pregnancy rate in mares. Vet. Rec. 28, 455-460

Reilas T., T. Katila, O. Makela, M. Huhtinen and E. Koskinen (1997): Intrauterine fluid accumulation in oestrous mares. Acta Vet. Scand. $38,69-78$

Ricketts S. W. and S. Alonso (1991): The effect of age and parity on the development of equine chronic endometrial disease. Equine.Vet. J. .23, 189-192

Schilela A., E. Malschitzky, A. L. G. Mattos, P. Garbade, R. M. Gregory and R. C. Mattos (2001): Effect of accumulation of intra-uterine fluid before and after the first postpartum ovulation on pregnancy rates in the mare. Pferdeheilkunde 17, 639-643

Schoon H-A., D. Schoon and E. Klug (1997): Die Endometriumsbiopsie bei der Stute im klinish-gynaekologischen Kontext. Pferdeheilkunde 13, 453-464

Schoon H.A., I. Wiegandt, D. Schoon, H. Aupperle and C. P. Bartmann (1997): Functional disturbances in the endometrium of barren mares: a histological and immunohistological study. J. Reprod.Fert. Supplement 56, 381-391

Troedsson M. H. T. (1997a): Diseases of the uterus. In: Robinson, N.E. Current Therapy on Equine Medicine 4. Philadelphia, W.B.: Saunders, 517-524

Troedsson M. H. T. (1997b): Therapeutic considerations for matinginduced endometritis. Pferdeheilkunde 13, 516- 520

Vieira M. J., A. K. Hött, E. Malschitzky, A. Keller, V. B. Wald, A. L. G. Mattos, R. M. Gregory and R. C. Mattos (2002): Antimicrobial agents in extender and their effect on semen preservation and pregnancy rate of inseminated mares. Theriogenology 58, 667 670

Watson E. D. (2000). Post-breeding endometritis in the mare. Animal Reprod. Sci 60-61, 221-232

Zent W. W., M. H. T. Troedsson and J.-L. Xve (1988): Postbreeding uterine fluid accumulation in a normal population of thoroughbred mares: a field study. Proc. Soc. Theriogenol., Baltimore, 78-79

Prof. Dr. R.C. Mattos

Reprolab-Departamento de Medicina Animal

Faculdade de Veterinária

Universidade Federal do Rio Grande do Sul

Av. Bento Gonçalves 9090

91570-000 Porto Alegre - RS, Brazil

rcmattos@ufrgs.br 